\title{
PERAN MEDIASI MOTIVASI KERJA PADA PENGARUH GAYA KEPEMIMPINAN TRANSAKSIONAL DAN KOMPENSASI TERHADAP KINERJA KARYAWAN
}

\author{
Ratna Andriya Ulfah \\ Didik Subiyanto \\ Ignatius Soni Kurniawan \\ Universitas Sarjanawiyata Tamansiswa \\ didiks@ustjogja.ac.id
}

\begin{abstract}
This study aims to examine the effect of transactional leadership style and compensation on employee performance mediated by work motivation on the employees of the Sleman Regency. Sampling in this study uses probability method because the population of employees in the Regional Water Supply Company (PDAM) Sleman Regency is quite a lot to be studied. Data collection techniques using a questionnaire distributed by the Director of PDAM Sleman. Data analysis techniques using the application SPSS version 21 include validity test, reliability test, descriptive statistics, classic assumption test, multiple linear regression test, hypothesis test, and coefficient of determination. The results of this study indicate that the transactional leadership style variable has a positive and significant effect on work motivation, compensation has a positive and significant effect on work motivation, transactional leadership has a positive and significant effect on employee performance, work motivation has a positive and significant effect on employee performance, compensation has a positive and significant effect on employee performance, transactional leadership has a positive and significant effect on employee performance mediated by motivation, compensation has a positive and significant effect on employee performance mediated by motivation. The most dominant influence is work motivation variable, then compensation variable is followed.
\end{abstract}

Keywords: Transactional Leadership Style; Compensation; Work Motivation; Performance.

\section{PENDAHULUAN}

Perkembangan teknologi yang sangat cepat menuntut kemampuan Manajemen Sumber Daya Manusia (MSDM) untuk juga terus berkembang, mengingat MSDM adalah suatu agen perubahan. Sumber Daya Manusia (SDM) menjadikan salah satu fokus yang penting bagi sebuah organisasi dalam mencapai persaingan yang unggul dalam menentukan keberhasilan. Oleh karena itu, SDM dalam proses manajemen harus harmonis untuk menciptakan suatu tujuan yang efektif dan efisien. Untuk mencapai tujuan tersebut sebuah organisasi memerlukan SDM yang berkualitas yang mampu menjadi penggerak. Karyawan merupakan aset yang paling utama dimana seorang karyawan mempunyai pikiran, perasaan yang akan menjadi perencana, pelaksana, dan dapat menjadi penggendali yang memiliki peran aktif untuk mewujudkan visi misi suatu organisasi.

Untuk dapat mewujudkan visi dan misi suatu organisasi tentu sangat membutuhkan SDM yang berkompeten sesuai dengan bidangnya. Seperti yang diketahui bahwa SDM merupakan salah satu faktor penghubung rantai kesuksesan organisasi dalam mewujudkan tujuan organisasi yang telah ditentukan. Hal ini 
menjadikan SDM sebuah fenomena yang mana organisasi tidak hanya fokus dengan laba atau rugi kentungan akan tetapi juga memperhatikan SDM-nya. Untuk meningkatkan kinerja, persahaan tidak hanya mengendalikan pada mesin modern, modal yang memadai, dan juga bahan baku yang lengkap tetapi yang paling utama adalah faktor tenaga kerja dalam hal ini adalah karyawan.

Perusahaan Daerah Air Minum (PDAM) merupakan perusahaan milik daerah yang bergerak dalam penyedia air bersih untuk masyarakat umum yang diawasi dan dimonitor oleh legislatif daerah. PDAM tersedia di setiap provinsi, kabupaten dan kotamadya yang ada di seluruh Indonesia. PDAM Kabupaten Sleman merupakan pengelolaan usaha milik daerah Kabupaten Sleman yang telah bertahun-tahun mendistribusikan air bersih bagi masyarakat di daerah tersebut.

Berdasarkan fenomena yang ada di lapangan, pemimpin PDAM Kabupaten Sleman belum sepenuhnya bisa dalam memotivasi karyawannya, sehingga motivasi kinerja menurun. Kurangnya apresiasi kompensasi kepada karyawan terhadap hasil kerja yang telah dilakukan, menyebabkan karyawan menyelesaikan beberapa pekerjaan tidak tepat waktu.

Pengembangan SDM di dalam suatu organisasi tidak lepas dari peran aktif manajemen dalam mengupayakan peningkatan produktivitas kerja karyawannya dan tentunya untuk perusahaan. Peningkatan produktivitas bagi kinerja akan berjalan dengan baik jika organisasi tersebut memiliki karyawan yang berkompeten di bidangnya. Seperti yang diketahui bahwa kinerja merupakan hasil pencapaian seorang karyawan sesuai prosedur yang berlaku untuk pekerjaan yang bersangkutan, sehingga seorang karyawan merupakan faktor utama yang sangat berharga yang harus dikelola dengan baik oleh perusahaan agar dapat memberikan kontribusi yang optimal berwujud kinerja (Deiva, 2017). Salah satu prinsip yang dijunjung tinggi oleh suatu perusahaan yang ingin berkembang dan maju adalah meningkatkan kinerja karyawan, karena setiap karyawan memiliki tugas dan pekerjaan masing-masing dan ketika seorang karyawan dapat memenuhi tugas dan target yang diberikan oleh perusahaan, maka dapat dikatakan bahwa karyawan tersebut memiliki tingkat kinerja yang baik. Hasil penelitian Komardi (2009) memberi pandangan bahwa kinerja setiap karyawan berpengaruh terhadap kepuasan kerja melalui beberapa faktor seperti pimpinan, kemampuan diri, motivasi, rekan kerja, dan lingkungan kerja.

Kinerja karyawan dapat ditingkatkan melalui motivasi. Menurut Kasenda (2013) motivasi merupakan keadaan yang menggambarkan kemauan dan usaha keras seseorang diarahkanpadahasiluntukpencapaian tujuan tertentu. Maksud dari hasil tersebut bisa berupa kreativitas, kehadiran bahkan perilaku. Berdasarkan teori di atas dapat diambil kesimpulan bahwa kinerja karyawan memiliki pengaruh terhadap motivasi kerja. Motivasi kerja dapat disalurkan melalui kemampuan prestasi kerja, komitmen organisasi, dan produktivitas kerja karena motivasi memiliki peran aktif dalam mempengaruhi sikap dan perilaku pada masing-masing individu pada saat bekerja. Maka dari itu organisasi harus memperhatikan kebutuhan karyawannya agar motivasi diri karyawan meningkat dan mampu menghasilkan kinerja yang baik.

Selain motivasi kerja, kompensasi merupakan hal yang diinginkan seorang karyawan atas usaha yang telah dikerjakan guna mengarahkan karyawan untuk meningkatkan kinerjanya. Menurut Sastrohadiwiryo (2003) kompensasi merupakan balas jasa yang diberikan pada tenaga kerja oleh perusahaan karena telah memberikan kontribusi berupa tenaga dan pikirannya demi kemajuan perusahaan guna mencapai tujuan yang telah ditetapkan baik dalam jangka panjang maupun jangka pendek. Kompensasi diberikan dengan tujuan memberikan tindakan dan memotivasi kepada kinerja karyawan untuk meningkatkan motivasi kerja agar dapat mencapai sasaransasaran organisasi. Kompensasi bisa berupa fisik dan non fisik dan diberikan kepada karyawan sesuai dengan kontribusi yang telah 
diberikan pada organisasi. Rizal (2014) telah menguji bahwa kompensasi memiliki pengaruh langsung terhadap kinerja karyawan.

Gaya kepemimpinan merupakan salah satu faktor penting pendorong kesuksesan sebuah perusahaan. Sedangkan pendapat lain menyebutkan bahwa gaya kepemimpinan adalah karakteristik yang dipergunakan pemimpin untuk mempengaruhi karyawannya agar dapat mencapai sasaran organisasi yang telah dituju atau dapat pula dikatakan bahwa gaya kepemimpinan merupakan sistem dan strategi yang dikuasai dan sering diterapkan oleh pemimpin (Rivai, 2014). Berdasarkan definisi yang dikemukakan oleh Rivai (2014), maka dapat ditarik kesimpulan bahwa gaya kepemimpinan merupakan suatu pola tindakan yang dipersepsikan kepada seorang karyawan guna mengarahkan, mengendalikan, dan mempengaruhi orang lain yang berhubungan dengan aktivitas pekerjaan untuk mencapai suatu tujuan tertentu.

Salah satu gaya gaya kepemimpinan yang dapat mengembangkan karyawan melalui produktivitas dan dapat meningkatkan motivasi dalam menjalankan pekerjaannya adalah gaya kepemimpinan transaksional. Gaya kepemimpinan transaksional merupakan gaya kepemimpinan yang mengaitkan suatu proses pertukaran yang melibatkan seorang karyawan mendapatkan reward atau imbalan serta membantu karyawannya untuk mengenali sesuatu yang harus dilakukan untuk mendapatkan hasil yang diinginkan seperti kualitas pelayanan yang lebih baik (Hakim, 2017).

Penelitian yang dilakukan Septiana (2013) menyatakan bahwakepemimpinan transaksional terbukti berpengaruh langsung terhadap kinerja dan motivasi. Menurut Barling et al., (1999) dalam penelitiannya menyatakan bahwa kepemimpinan transaksional berpengaruh terhadap kinerja karyawan yang dimediasi oleh motivasi. Hal ini menyatakan bahwa kepemimpinan transaksional di dalam organisasi dapat berperan langsung dalam mempengaruhi kinerja dan motivasi karyawan.

\section{REVIEW LITERATUR DAN HIPOTESIS}

\section{Landasan Teori}

1. Kinerja

Menurut Prawirosentono (2008) kinerja adalah hasil kerja yang dapat dicapai seorang individu maupun kelompok dalam suatu organisasi sesuai dengan tanggung jawab masing-masing dalam mencapai tujuan organisasi yang bersangkutan secara legal tidak melanggar hukum dan sesuai dengan etika.

2. Gaya Kepemimpinan Transaksional

Menurut Rivai (2014) mengemukakan bahwa gaya kepemimpinan merupakan sekelompok ciri yang dipergunakan oleh seorang pemimpin untuk mempengaruhi karyawannya agar dapat mencapai tujuan di dalam sebuah organisasi. Kepemimpinan transaksional menjelaskan fokus perhatiannya pada transaksi interpersonal antara pemimpin dengan bawahannya yang melibatkan hubungan pertukaran yang didasarkan pada kesepakatan mengenai klasifikasi sasaran, standar kerja yang telah ditentukan, dan penugasan kerja serta penghargaan berupa insentif dan imbalan atas pemenuhan tugas yang telah dilakukannya.

3. Kompensasi

Menurut Gaol dalam Onsardi (2017) kompensasi merupakan suatu imbalan yang diterima baik dalam bentuk uang atau bukan uang sebagai bentuk balas jasa yang diberikan untuk upaya karyawan kepada organisasi.

4. Motivasi Kerja

Menurut Sopiah dalam Kasenda (2013) motivasi merupakan keadaan dimana kemauan dan usaha keras seseorang diarahkan pada hasil-hasil pencapaian tujuan tertentu. Hasil tersebut bisa berupa produktivitas, kehadiran, atau pengembangan ide-ide kreatif lainnya. Kesediaan seseorang untuk melakukan pekerjaan disebabkan dengan adanya 
dorongan yang kuat agar dapat mencapai tujuan perusahaan, maka kekuatan dorongan inilah yang disebut dengan motivasi kerja.

\section{Hipotesis}

1. Pengaruh Gaya Transaksional terhadap Motivasi Kerja

Menurut Bass dalam Septiana (2013) gaya kepemimpinan transaksional adalah pemimpin yang mampu memberikan motivasi kepada bawahannya yang melibatkan hubungan pertukaran dengan cara menukar imbalan untuk pekerjaan yang telah dilakukannya. Imbalan yang dimaksudkan tersebut bisa berupa penghargaan atau upah bagi karyawan yang menghasilkan kinerja melebihi target yang ditentukan atau pemimpin memberikan sanksi bagi karyawan yang kinerjanya di bawah target. Kepemimpinan transaksional sebagai cara untuk mencapai tujuan bersama antara pemimpin dan bawahan dengan meningkatkan perhatian kepada karyawan sehingga kinerjanya akan meningkat. Gaya kepemimpinan transaksional merupakan kepemimpinan yang sangat pantas untuk digunakan di dalam organisasi, karena dalam membuat panduan kinerja harus disertai dengan mengenali bawahannya terlebih dahulu. Berdasarkan penelitian terdahulu yang dilakukan oleh Awan (2014) pada PT. Wijaya Sukses Sejahtera di Kabupaten Berau menunjukkan hasil bahwa kepemimpinan transaksional berpengaruh positif terhadap motivasi kerja. Dengan demikian, hipotesis yang dapat dibentuk adalah:

\section{H1: Kepemimpinan Transaksional Berpengaruh Positif terhadap Motivasi Kerja.}

\section{Pengaruh Kompensasi terhadap Motivasi Kerja}

Kompensasi adalah segala sesuatu yang diterima oleh karyawan secara langsung maupun tidak langsung, baik berupa imbalan maupun reward atas jasa yang telah dilakukan sesuai dengan pekerjaannya. Dengan adanya kompensasi diharapkan akan meningkatkan motivasi kerja dan kinerja karyawan (Nikoyama, 2019). Berdasarkan penelitian terdahulu yang dilakukan oleh Nikoyama (2019) pada perbankan di Provinsi Lampung menunjukkan hasil bahwa kompensasi memiliki pengaruh positif terhadap motivasi kerja. Dengan demikian, hipotesis yang dapat dibentuk adalah:

\section{H2 : Kompensasi Berpengaruh Positif terhadap Motivasi Kerja.}

\section{Pengaruh Gaya Kepemimpinan Transaksional terhadap Kinerja Karyawan}

Kepemimpinan transaksional melakukan pendekatan kepada bawahannya dengan mengenali bawahannya terlebih dahulu. Hubungan pemimpin transaksional dengan karyawannya terlihat dari tiga hal, di antaranya pemimpin transaksioal harus mengetahui apa yang dibutuhkan karyawannya guna menjalankan kinerjanya di perusahaan tersebut dan menjelaskan kepadakaryawannya apa yang akan mereka dapatkan apabila seorang karyawan menjalankan kinerjanya sesuai dengan harapan. Selanjutnya, pemimpin menjalankan hubungan pertukaran kepada karyawannya berupa imbalan atas usaha yang telah dijalankan oleh seorang karyawan dan pemimpin harus tanggap terhadap kepentingan pribadi seorang karyawan selama kepentingan tersebut sebanding dengan nilai pekerjaan yang telah dilakukannya.

Berdasarkan penelitian yang dilakukan oleh Mahdinezhad (2013) menjelaskan bahwa terdapat pengaruh positifdan signifikan antara kepemimpinan transaksional dengan kinerja. Dengan demikian, hipotesis yang dapat dibentuk adalah: 


\section{H3 :Kepemimpinan Transaksional Berpengaruh Positif terhadap Kinerja Karyawan.}

\section{Pengaruh Motivasi Kerja terhadap} Kinerja Karyawan

Motivasi adalah dorongan dan keinginan aktif di dalam diri manusia, yang dapat mengarahkan perilakunya untuk melaksanakan tugas dan tanggung jawab dalam lingkungan pekerjaan (Rahmawati, 2016). Motivasi dalam penelitian ini tercipta berdasarkan kompensasi dan gaya kepemimpinan transaksional dari seorang pemimpin. Dengan adanya kompensasi dan gaya kepemimpinan yang baik maupun kurang baik akan mempengaruhi motivasi karyawan sehigga akan berdampak terhadap kinerja karyawannya.

Berdasarkan penelitian terdahulu yang dilakukan oleh Nikoyama (2019) di perbankan Provinsi Lampung menunjukkan bahwa motivasi memiliki pengaruh positif terhadap kinerja karyawan. Dengan demikian, hipotesis yang dapat dibentuk adalah:

\section{H4 : Motivasi Kerja Berpengaruh Positif terhadap Kinerja Karyawan}

\section{Pengaruh Kompensasi terhadap} Kinerja Karyawan

Menurut Hasibuan (2012) kompensasi adalah salah satu upaya yang dilakukan oleh perusahaan untuk meningkatkan kinerja seorang karyawan dengan memberikan timbal balik atas partisipasi yang diberikan. Hal ini dilakukan agar karyawan merasa terdorong untuk selalu berusaha meningkatkan kinerjanya karena karyawan akan menerima imbalan sesuai dengan kinerja yang telah dilakukannya.

Berdasarkan penelitian terdahulu yang dilakukan oleh Rahmawati (2016) di kantor Dinas Pendapatan Pengelolaan Keuangan dan Aset Daerah (DPPKAD) Kabupaten Karanganyar menunjukkan bahwa kompensasi memiliki pengaruh positif terhadap kinerja karyawan. Dengan demikian, hipotesis yang dapat dibentuk adalah:

\section{H5 :Kompensasi Berpengaruh Positif terhadap Kinerja Karyawan}

\section{Pengaruh Gaya Kepemimpinan Transaksional terhadap Kinerja Karyawan yang Dimediasi oleh Motivasi}

Penelitian mengenai kepemimpinan transaksional mempertimbangkan dua karakteristik utama tipe kepemimpinan transaksional, yaitu pemimpin transaksional menggunakan serangkaian imbalan atau balas jasa untuk memotivasi para karyawannya dan pemimpin hanya melakukan tindakan koreksi apabila karyawannya tidak dapat mencapai target yang sudah ditentukan oleh perusahaan. Dengan ini pemimpin transaksional mengarah pada upaya mempertahankan keadaan yang telah dicapai. Gaya kepemimpinan yang dimiliki oleh seorang pemimpin telah terbukti mempengaruhi kinerja karyawannya. Motivasi telah terbukti memiliki peran mediasi dalam hubungan kepemimpinan transaksional terhadap kinerja (Septiana, 2013). Dengan demikian, hipotesis yang dapat dibentuk adalah:

\section{H6 :Kepemimpinan Transaksional Berpengaruh Positif terhadap Kinerja Karyawan yang Dimediasi oleh Motivasi.}

7. Pengaruh Kompensasi Terhadap Kinerja Karyawan yang Dimediasi oleh Motivasi

Menurut Hasibuan dalam Dito (2010) mengatakan bahwa salah satu pemberian kompensasi adalah motivasi. Jika pemberian kompensasi atau balas jasa yang diberikan cukup besar, maka pemimpin akan mudah dalam memotivasi karyawannya. Menurut Robbins (2011) motivasi adalah proses yang memiliki peran yang lebih mengarahkan individu 
ke arah pencapaian yang akan dituju. Apabila seorang karyawan menganggap bahwa kompensasi yang diberikan oleh perusahaan sesuai dengan apa yang diharapkan, maka akan dapat memotivasi karyawan untuk meningkatkan kinerjanya. Berdasarkan penelitian terdahulu yang dilakukan oleh Dito (2010) di PT. Slamet Langgeng Purbalingga menunjukkan bahwa motivasi telah terbukti memiliki peran mediasi pada pengaruh kompensasi terhadap kinerja karyawan. Dengan demikian, hipotesis yang dapat dibentuk adalah:

\section{H7 :Kompensasi Berpengaruh Positif terhadap Kinerja Karyawan yang Dimediasi oleh Motivasi.}

\section{Model Penelitian}

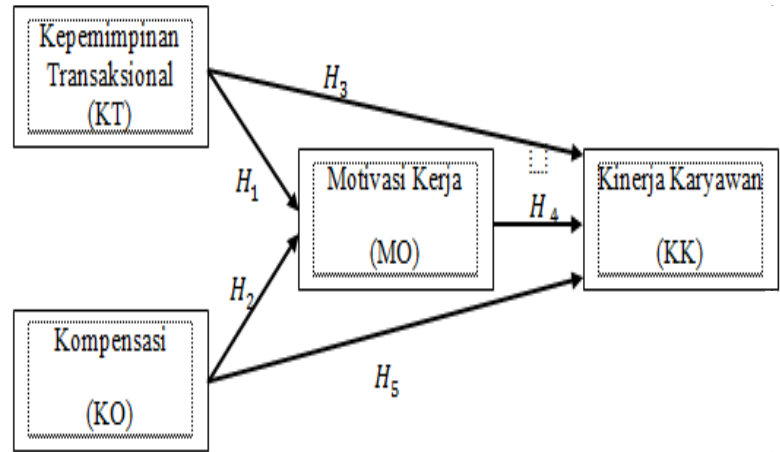

Gambar 1. Model Penelitian

\section{METODE PENELITIAN}

\section{Populasi dan Sampel}

Populasi merupakan wilayah yang terdiri atas obyek atau subjek yang mempunyai kualitas dan karakteristik tertentu yang diterapkan oleh peneliti untuk dipelajari dan kemudian ditarik kesimpulan (Sugiyono, 2014). Dalam penelitian ini populasinya adalah seluruh karyawan pusat PDAM Kabupaten Sleman, DIY yang berjumlah 173 karyawan.

Menentukan besarnya sampel dapat menggunakan statistik atau berdasarkan estimasi penelitian. Sampel pada penelitian ini adalah karyawan yang bekerja di PDAM
Kabupaten Sleman yang berada di Jalan Parasamya 18 Sleman, DIY. Metode pada penelitian ini menggunakan metode sensus dan disederhanakan menggunakan metode Slovin. Jadi, sampel yang digunakan pada penelitian ini yaitu berjumlah yang dibulatkan menjadi 64 responden, yang telah dihitung menggunakan metode Slovin.

\section{Definisi Operasional}

\section{Variabel Dependen}

Variabel dependen atau sering disebut variabel terikat merupakan variabel yang dipengaruhi atau yang menjadi akibat karena adanya variabel bebas (Sugiyono, 2014). Variabel dependen dalam penelitian ini adalah kinerja karyawan (Y). Kinerja karyawan merupakan hasil kerja yang dicapai oleh seorang karyawan baik kualitas maupun kuantitas berdasarkan pekerjaan dan tanggung jawabnya dari masing-masing karyawan yang telah ditentukan oleh organisasi.

\section{Variabel Independen}

Variabel independen atau sering disebut juga dengan variabel bebas. Menurut Sugiyono (2014) variabel independen merupakan variabel yang dapat mempengaruhi atau menjadi penyebab perubahan atau timbulnya variabel independen. Pada penelitian ini terdapat dua variabel independen yaitu kepemimpinan transaksional $\left(\mathrm{X}_{1}\right)$ dan kompensasi $\left(\mathrm{X}_{2}\right)$.

a. Kepemimpinan Transaksional $\left(\mathrm{X}_{1}\right)$

Menurut Bass dalam Septiana (2013) pemimpin transaksional yang efektif mampu membantu kepentingan karyawannya dengan memberikan insentif, penghargaan, dan memenuhi janji pada saat karyawan mampu memenuhi tugas dan tanggung jawabnya terhadap komitmen pemimpin maupun organisasi. 


\section{b. Kompensasi $\left(\mathbf{X}_{2}\right)$}

Kompensasi merupakan bentuk imbalan jasa atau balas jasa yang diberikan oleh perusahaan sebagai penghargaan pada karyawan yang telah memberikan kontribusinya berupa waktu, tenaga dan pikirannya dalam mewujudkan tujuan perusahaan.

\section{Variabel Mediasi}

Variabel mediasi dalam penelitian ini adalah motivasi kerja (Z). Motivasi kerja merupakan daya dorong untuk mempengaruhi dan mengarahkan perilaku karyawan pada pencapaian tugas-tugas yang telah diterimanya guna mencapai suatu tujuan organisasi.

\section{Uji Kualitas Data}

\section{Uji Validitas}

Uji validitas digunakan untuk mengukur valid atau tidaknya kuesioner. Untuk melakukan uji validitas menggunakan program SPSS. Kuesioner dapat dikatakan valid apabila pertanyaan kuesioner mampu untuk mengungkapkan sesuatu yang akan diukur oleh kuesioner tersebut. Validitas digunakan untuk mengetahui kesamaan antara data yang terkumpul dengan data yang sesungguhnya terjadi pada obyek yang diteliti, sehingga mendapatkan data yang valid.

Dalam penelitian ini uji validitas dapat dikatakan valid apabila memiliki nilai probabilitas tingkat signifikansi lebih kecil atau sama dengan 5\% $(\leq 0,05)$ (Ghozali, 2011). Sedangkan untuk mengetahui skor masing-masing item pertanyaan valid atau tidak, maka ditetapkan kriteria statistik sebagai berikut: a) jika $r_{\text {hitung }}>r_{\text {tabel }}$ dan bernilai positif, maka variabel tersebut dinyatakan valid. b) jika $\mathrm{r}_{\text {hitung }}<\mathrm{r}_{\text {tabel }}$, maka variabel tersebut dinyatakan tidak valid. c) jika $r_{\text {hitung }}>r_{\text {tabel }}$ tetapi bertanda negatif, maka $\mathrm{H} 0$ akan tetap ditolak dan H1 dinyatakan diterima.

\section{Uji Reliabilitas}

Reliabilitas adalah alat untuk mengukursuatukuesioneryangmerupakan indikator dari variabel atau konstruk. Suatu kuesioner dikatakan reliabel jika jawaban seseorang terhadap pertanyaan adalah konstan atau stabil. Pengukuran reliabilitas ini dilakukan dengan cara one shot atau pengukuran sekali dan kemudian dibandingkan dengan pertanyaan lain atau mengukur korelasi antar jawaban pertanyaan dan pengukuran dengan cara repeated measure atau pengukuran yaitu seseorang yang akan diberi pertanyaan yang sama pada waktu yang berbeda dan kemudian dapat dilihat apakah dia tetap konsisten dengan jawabannya atau tidak (Ghozali, 2011).

Dalam penelitian ini uji reliabilitas dilakukan dengan menggunakan rumus Cronbach's Alpha $(\alpha)$. Dimana suatu instrumen dapat dikatakan reliabel bila memiliki koefisien alpha sebesar 0,6 atau lebih (Nonnally dalam Ghozali, 2011).

\section{Teknik Analisis Data}

\section{Analisis Statistik Deskriptif}

Analisis deskriptif merupakan penelitian yang dilakukan untuk mengetahui nilai variabel mandiri, baik satu variabel atau lebih tanpa membuat perbandingan atau menghubungkan dengan variabel lainnya (Ghozali, 2011). Analisis deskriptif digunakan untuk menganalisis dan menyajikan data kuantitatif dengan tujuan untuk mengetahui gambaran perusahaan yang dijadikan sampel penelitian. Dengan menggunakann analisis deskriptif dapat diketahui nilai rata-rata (mean), standar deviasi, maksimum dan minimum (Ghozali, 2011). Karakteristik responden yang digunakan dalam penelitian ini diklasifikasikan berdasarkan jenis kelamin, usia, pendidikan terakhir pada responden. 


\section{Analisis Asumsi Klasik}

a. Normalitas

Uji normalitas digunakan untuk menguji variabel penelitian memiliki distribusi normal atau tidak (Ghozali, 2011). Diketahui bahwa uji T mengasumsikan bahwa nilai residual mengikuti distribusi normal. Pengujian uji normalitas dalam penelitian ini menggunakan uji statistik normal probability plot dan Kolmogorov-smirnov test. Pengujian ini dilakukan dengan menilai 2-tailed signifikan melalui pengaruh tingkat signifikansi 5\%. Data dikatakan normal apabila Asymp. Sig (2-tailed) lebih besar dari 0,05 . Jika nilai signifikansi $<0,05$, maka disimpulkan bahwa distribusi residual dapat peneliti tidak normal.

\section{b. Heteroskedastisitas}

Menurut Ghozali (2011) uji heterokedastisitas bertujuan untuk menguji sama atau tidak varian dan residual dari observasi satu dengan observasi yang lainnya. Jika residualnya mempunyai varian yang sama disebut homokedastisitas, tetapi jika variansnya tidak sama disebut heteroskedastisitas. Cara mendeteksi ada tidaknya heteroskedastisitas dengan cara melihat grafik plot antara nilai prediksi variabel terikat atau dependen, yaitu ZPRED dengan residualnya SREID dapat dilihat dengan ada tidaknya pola penentu pada grafik scatterplot antara SREID dan ZPRED dimana sumbu $\mathrm{Y}$ adalah $\mathrm{Y}$ yang diprediksi dan sumbu $X$ adalah residual ( $Y$ prediksi-Y sesungguhnya) yang telah di studentized. Selanjutnya, menggunakan uji glejser yaitu apabila nilai signifikansi (Sig.) lebih besar dari 0,05, maka kesimpulannya adalah tidak terjadi gejala heteroskedastisitas dalam model regresi. Jika nilai signifikansi
(Sig.) lebih kecil dari 0,05, maka kesimpulannya adalah terjadi gejala heteroskedastisitas dalam model regresi.

\section{c. Multikolinieritas}

Multikolinieritas adalah situasi dimana terdapat korelasi variabelvariabel bebas di antara satu dengan yang lainnya. Menurut (Ghozali, 2013) uji multikolinieritas bertujuan untuk menguji apakah regresi ditemukan adanya korelasi antara variabel bebas dan variance inflantion factor's (VIF). Suatu model regresi bebas dari multikolinieritas adalah mempunyai nilai VIF $<10$ dan mempunyai tolerance $>10$ (Ghozali, 2013).

\section{Metode Analisis Data}

\section{Analisis Regresi Linier Berganda}

Penelitian yang dilakukan peneliti merupakan metode kuantitatif. Pengujian analisis menggunakan analisis regresi berganda yang dioperasikan melalui program SPSS. Menurut Sugiyono (2014) analisis regresi berganda digunakan untuk mengetahui pengaruh dari variabel bebas $(\mathrm{X})$ terhadap variabel terikat (Y). Persamaan ini menggunakan persamaan regresi sebagai berikut:

\section{a. Regresi Model 1 (Motivasi Kerja)}

Analisis regresi model 1 digunakan untuk mengetahui besarnya pengaruh langsung dari variabel kepemimpinan transaksional dan kompensasi terhadap motivasi kerja. Persamaan regresi sebagai berikut:

Persamaan: $Z=a+b_{1} X_{1}+b_{2} X_{2}$

Keterangan:

$\mathrm{Z}=$ Motivasi Kerja

$\mathrm{X}_{1}=$ Kepemimpinan Transaksional

$\mathrm{X}_{2}=$ Kompensasi

a $=$ Konstanta

$\mathrm{b}_{1}=$ Koefisien regresi $\mathrm{X}_{1}$

$b_{2}=$ Koefisien regresi $X_{2}$ 


\section{b. Regresi Model 2 (Kinerja Karyawan)}

Analisis regrsi model 2 digunakan untuk mengetahui besarnya pengaruh kepemimpinan transaksional, kompensasi, dan motivasi kerja terhadap kinerja karyawan. Persamaan regresi sebagai berikut:

Persamaan: $\mathrm{Y}=\mathrm{a}+\mathrm{b}_{1} \mathrm{X}_{1}+\mathrm{b}_{2} \mathrm{X}_{2}+$ $\mathrm{bZ}$

Keterangan:

$\mathrm{Y}=$ Kinerja Karyawan

$\mathrm{X}_{1}=$ Kepemimpinan Transaksional

$\mathrm{X}_{2}=$ Kompensasi

bZ $=$ Koefisien Regresi Mediasi Motivasi Kerja

a $=$ Konstanta

$\mathrm{b}_{1}=$ Koefisien Regresi $\mathrm{X}_{1}$

$\mathrm{b}_{2}=$ Koefisien Regresi $\mathrm{X}_{2}$

\section{Uji Hipotesis}

\section{Uji Parsial (Uji T)}

Uji T dilakukan untuk mengetahui seberapa jauh pengaruh variabel independen secara individu dalam menerangkan variasi variabel dependen (Ghozali, 2013). Kriteria dalam menentukan uji $\mathrm{T}$ adalah ketika sig $<0,05$ atau $=0,05$, maka dapat dikatakan bahwa suatu variabel independen mempengaruhi variabel dependen atau hipotesis diterima, jika nilai signifikansi lebih besar maka dapat dikatakan hipotesis ditolak (Ghozali, 2013). H0 diterima apabila $t_{\text {hitung }}<t_{\text {tabel }}$, maka H0 diterima, H0 ditolak apabila $\mathrm{t}_{\text {hitung }}>\mathrm{t}_{\text {tabel }}$, maka H0 ditolak.

\section{Uji Sobel (Sobel Test)}

Pengujian terhadap peran penting dari variabel mediasi, yaitu motivasi kerja dapat dilakukan dengan menggunakan perhitungan sobel test. Sobel test dapat digunakan dengan menggunakan signifikansi dari pengaruh tidak langsung atau pengaruh mediasi dalam persamaan struktural (Sobel, 1982). Uji sobel ini dilakukan dengan cara menguji kekuatan pengaruh tidak langsung variabel independen $(\mathrm{X})$ kepada variabel dependen (Y) melalui variabel intervening (Z).

\section{Uji Koefisien Determinasi}

Perhitungan koefisien determinasi $\left(\mathrm{R}^{2}\right)$ pada intinya mengukur seberapa jauh kemampuan suatu model dalam menerangkan variasi dari variabel terikat (Ghozali, 2013). Koefisien determinasi $\left(\mathrm{R}^{2}\right)$ dimaksud untuk mengetahui tingkat ketepatan paling baik dalam analisis regresi. Nilai yang mendekati 1 (satu) berarti model regresi variabel independen terhadap dependen sangat berpengaruh sebesar nilai $\mathrm{R}^{2}$ dan sebaliknya.

\section{Standardized Beta Coefficient}

Pengujian mengenai variabel independen dominan mempengaruhi dependen dalam suatu model regresi linier berganda, dengan melihat nilai Standardized Beta Coeffcient pada uji linier regresi berganda.

\section{HASIL PENELITIAN DAN PEMBAHASAN}

\section{Hasil Penelitian}

\section{Hasil Uji Validitas}

Tabel 4.1. Hasil Uji Validitas Gaya Kepemimpinan Transaksional

\begin{tabular}{ccccc}
\hline Variabel & Indikator & r-hitung & r-tabel & Keterangan \\
\hline \multirow{4}{*}{ Kepemimpinan } & KT1 & 0,730 & 0,2075 & Valid \\
& KT2 & 0,694 & 0,2075 & Valid \\
& KT3 & 0,752 & 0,2075 & Valid \\
& KT5 & 0,651 & 0,2075 & Valid \\
& KT6 & 0,540 & 0,2075 & Valid \\
& KT7 & 0,675 & 0,2075 & Valid \\
& KT8 & 0,752 & 0,2075 & Valid \\
& KT9 & 0,671 & 0,2075 & Valid \\
\hline
\end{tabular}

Berdasarkan tabel 4.1 uji validitas yang dilakukan dengan membandingkan $\mathrm{r}_{\text {hitung }}$ dengan $\mathrm{r}_{\text {tabel }}$ untuk (df) $=\mathrm{n}-2$ pada tingkat signifikansi. Suatu indikator dinyatakan valid apabila $r_{\text {hitung }}>r_{\text {tabel }}$. 
Jumlah data dalam penelitian ini (df) $=$ $64-2=62$ dengan hasil korelasi koefisien seluruhnya mempunyai nilai $r_{\text {hitung }}>r_{\text {tabel }}$ sebesar 0,2075. Dengan demikian dapat dinyatakan bahwa seluruh butir dari variabel kepemimpinan transaksional dinyatakan valid.

Tabel 4.2. Hasil Uji Validitas

\begin{tabular}{ccccc}
\multicolumn{5}{c}{ Kompensasi } \\
\hline Variabel & Indikator & r-hitung & r-tabel & Keterangan \\
\hline \multirow{5}{*}{ Kompensasi } & KO1 & 0,805 & 0,2075 & Valid \\
& KO2 & 0,819 & 0,2075 & Valid \\
& KO3 & 0,821 & 0,2075 & Valid \\
& KO4 & 0,736 & 0,2075 & Valid \\
& KO5 & 0,809 & 0,2075 & Valid \\
& KO6 & 0,808 & 0,2075 & Valid \\
& KO8 & 0,809 & 0,2075 & Valid \\
& KO9 & 0,741 & 0,2075 & Valid \\
& KO10 & 0,819 & 0,2075 & Valid \\
& & & & Valid \\
\hline
\end{tabular}

Berdasarkan tabel 4.2 hasil koefisien korelasi yang dilakukan dengan menghitung $r_{\text {hitung }}>r_{\text {tabel }}$ sebesar 0,2075. Dengan demikian dapat dinyatakan bahwa seluruh butir dari variabel kompensasi dinyatakan valid.

Tabel 4.3. Hasil Uji Validitas Motivasi

\begin{tabular}{ccccc}
\multicolumn{5}{c}{ Kerja } \\
\hline Variabel & Indikator & r-hitung & r-tabel & Keterangan \\
\hline \multirow{6}{*}{ Motivasi } & MO1 & 0,915 & 0,2075 & Valid \\
& MO2 & 0,775 & 0,2075 & Valid \\
& MO3 & 0,845 & 0,2075 & Valid \\
& MO4 & 0,653 & 0,2075 & Valid \\
& MO5 & 0,919 & 0,2075 & Valid \\
& MO6 & 0,892 & 0,2075 & Valid \\
& MO8 & 0,775 & 0,2075 & Valid \\
& MO9 & 0,845 & 0,2075 & Valid \\
& MO10 & 0,919 & 0,2075 & Valid \\
& & & & Valid
\end{tabular}

Berdasarkan tabel 4.3 hasil koefisien korelasi yang dilakukan dengan menghitung $r_{\text {hitung }}>r_{\text {tabel }}$ sebesar 0,2075. Dengan demikian dapat dinyatakan bahwa seluruh butir dari variabel motivasi kerja dinyatakan valid.
Tabel 4.4. Hasil Uji Validitas Kinerja Karyawan

\begin{tabular}{ccccc}
\hline Variabel & Indikator & r-hitung & r-tabel & Keterangan \\
\hline \multirow{6}{*}{ Kinerja } & KK1 & 0,789 & 0,2075 & Valid \\
& KK2 & 0,802 & 0,2075 & Valid \\
& KK3 & 0,799 & 0,2075 & Valid \\
& KK4 & 0,628 & 0,2075 & Valid \\
& KK5 & 0,833 & 0,2075 & Valid \\
& KK6 & 0,834 & 0,2075 & Valid \\
& KK7 & 0,800 & 0,2075 & Valid \\
& KK8 & 0,835 & 0,2075 & Valid \\
& KK9 & 0,769 & 0,2075 & Valid \\
& KK10 & 0,596 & 0,2075 & Valid \\
\hline
\end{tabular}

Berdasarkan tabel 4.4 hasil koefisien korelasi yang dilakukan dengan menghitung $\mathrm{r}_{\text {hitung }}>\mathrm{r}_{\text {tabel }}$ sebesar 0,2075. Dengan demikian dapat dinyatakan bahwa seluruh butir dari variabel kinerja karyawan dinyatakan valid.

\section{Uji Reliabilitas}

Tabel 4.5. Hasil Uji Reliabilitas

\begin{tabular}{lccc}
\hline \multicolumn{1}{c}{ Variabel } & $\begin{array}{c}\text { Cronbach's } \\
\text { Alpha }\end{array}$ & Kriteria & Kesimpulan \\
\hline Gaya Kepemimpinan & 0,910 & 0,600 & Reliabel \\
Kompensasi & 0,953 & 0,600 & Reliabel \\
Motivasi Kerja & 0,959 & 0,600 & Reliabel \\
Kinerja & 0,945 & 0,600 & Reliabel \\
\hline
\end{tabular}

Berdasarkan tabel 4.6 menunjukkan bahwa seluruh variabel memiliki nilai Cronbach's Alpha di atas 0,600. Dengan demikian, maka dapat dikatakan seluruh variabel dalam penelitian ini reliabel.

\section{Hasil Uji Asumsi Klasik}

\section{a. Normalitas}

Uji normalitas dalam penelitian ini dilakukan dengan cara melihat grafik normal probability plot. Gambar 4.1 merupakan grafik normal probability plot yang menunjukkan bahwa data menyebar di sekitar garis diagonal dan mengikuti arah garis diagonal. Gambar 4.2 grafik normal probability plot menunjukkan data menyebar di sekitar garis diagonal. Maka dapat dinyatakan bahwa data tersebut normal. 
Normal P.P Plot of Regression Standardized Residual Dependent Variable: MotivasI Kerja

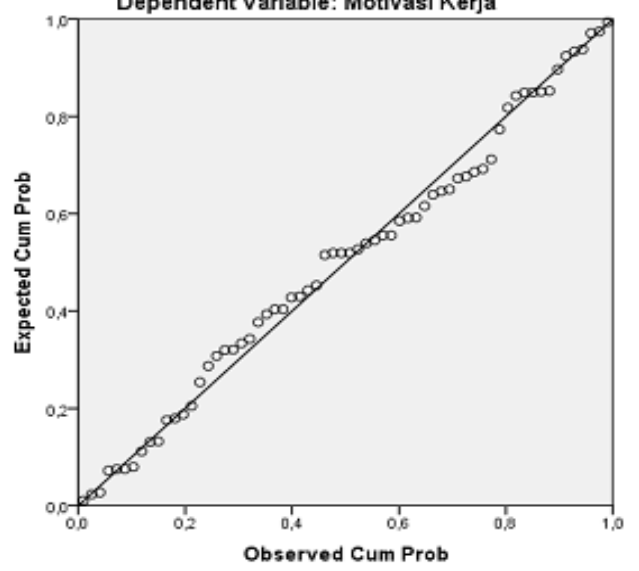

Gambar 4.1. Grafik Non Probability Plot Model I

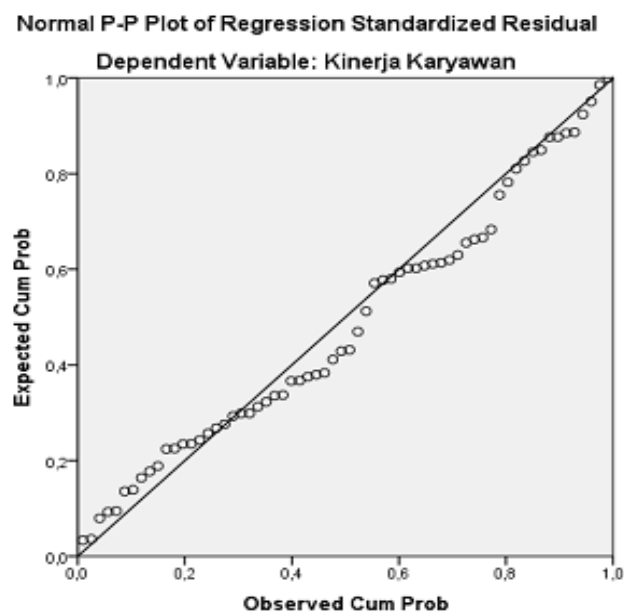

Gambar 4.2. Grafik Non Probability Plot Model II

Selain dengan grafik non probability plot dapat diuji dengan menggunakan uji KolmogrovSmirnov (K-S), dengan melihat tingkat signifikansinya. Data dinyatakan normal jika tingkat signifikansi $>0,05$.

Tabel 4.6

Uji Kolmogrov-Smirov 1

\begin{tabular}{lc}
\hline & Unstandardized Residual \\
\hline Kolmogrov- Smirnov Z & 0,566 \\
Asymp. Sig. (2-tailed) & 0,906 \\
\hline
\end{tabular}

Tabel 4.7

Uji Kolmogrov-Smirov 2

\begin{tabular}{lc}
\hline & Unstandardized Residual \\
\hline Kolmogrov- Smirnov Z & 0,760 \\
Asymp. Sig. (2-tailed) & 0,610 \\
\hline
\end{tabular}

Berdasarkan tabel 4.6 dijelaskan bahwa hasil uji normalitas mengunakanuji Kolmogorov-Smirnov hasil pengolahan data pada Asymp. Sig. (tailed) menunjukkan bahwa tingkat signifikansinya 0,906 . Tingkat signifikansi yang menunjukkan $0,906>0,05$ yang berarti bahwa data tersebut berdistribusi normal dan untuk tabel 4.7 nilai signifikansinya sebesar 0,610 yang menunjukkan bahwa $0,610>0,05$ maka data tersebut berdistribusi normal. Dapat disimpulkan dari kedua tabel bahwa data tersebut dinyatakan normal.

\section{b. Heteroskedastisitas}

Scatterplot

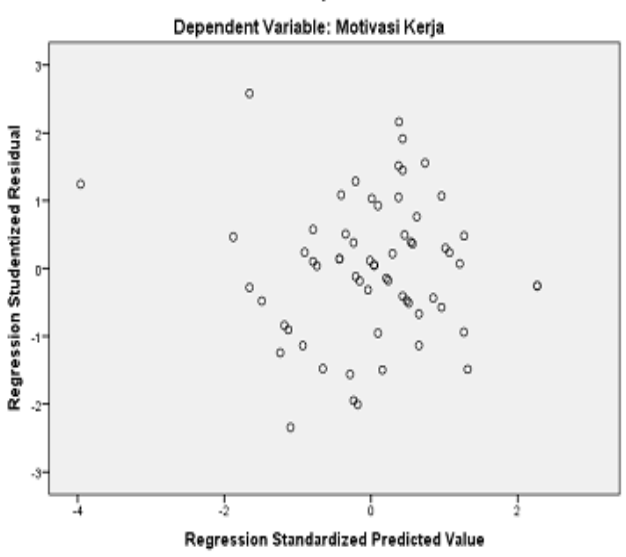

Gambar 4.3. Grafik Scatterplot Model I 


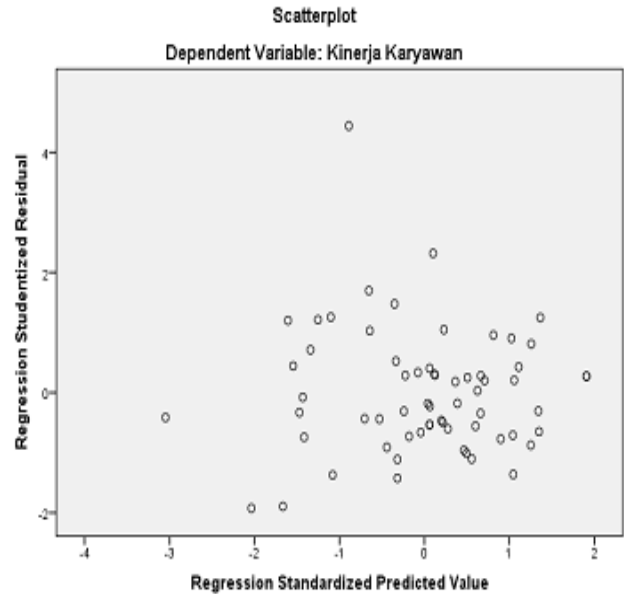

\section{Gambar 4.4. Grafik Scatterplot} Model II

Berdasarkan gambar 4.3 dan 4.4 bahwa tidak ada pola yang jelas, serta titik menyebar di atas dan di bawah angka 0 pada sumbu Y, maka dapat diambil kesimpulan bahwa dalam model regresi ini tidak terjadi heteroskedastisitas. Selain menggunakan grafik scatterplot, uji heteroskedastisitas dapat dilakukan pengujian dengan menggunakan uji glejser, dengan melihat nilai absolute dengan variabel independennya.

Tabel 4.8

Jji Glejser Heteroskededastisitas Model 1

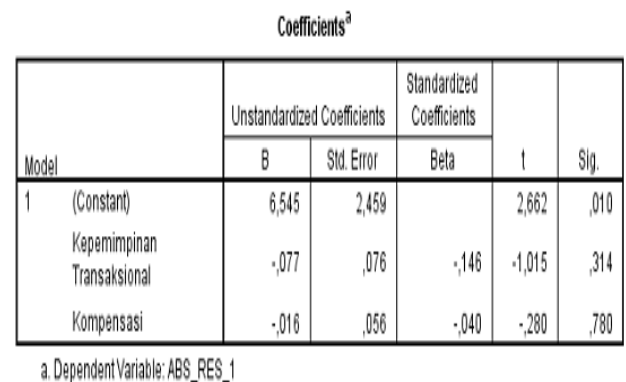

Tabel 4.9

Uji Glejser Heteroskedastisitas Model 2

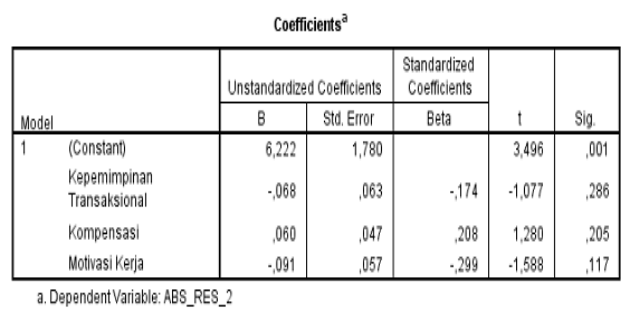

Berdasarkan tabel 4.8 hasil uji heteroskedastisitas melalui uji glejser menunjukkan nilai signifikansi 0,314 dan 0,780 yang lebih besar dari 0,05 dan tabel 4.9 uji glejser yang menunjukkan nilai signifikansi 0,286, 0,205 dan 0,117 nilai tersebut lebih besar dari 0,05 . Maka dapat disimpulkan bahwa hal ini menunjukkan tidak adanya heteroskedastisitas.

c. Multikolinieritas

Tabel 4.10

Uji Multikolinearitas

\begin{tabular}{c|c|c|c}
\hline Variabel & Tolerance & VIF & Keterangan \\
\hline $\begin{array}{c}\text { Kepemimpinan } \\
\text { Transaksional }\end{array}$ & .567 & 1.764 & Tidak terjadi Multikolinearitas \\
\hline Kompensasi & .558 & 1.792 & Tidak terjadi Multikolinearitas \\
\hline
\end{tabular}

Tabel 4.11

Uji Multikolinearitas

\begin{tabular}{c|c|c|c}
\hline \multicolumn{1}{c|}{ Variabel } & Tolerance & VIF & Keterangan \\
\hline $\begin{array}{l}\text { Kepemimpinan } \\
\text { Transaksional }\end{array}$ & .567 & 1.764 & Tidak terjadi Multikolinearitas \\
\hline Kompensasi & .558 & 1.792 & Tidak terjadi Multikolinearitas \\
\hline Motivasi Kerja & .417 & 2.400 & Tidak terjadi Multikolinearitas \\
\hline
\end{tabular}

Dari tabel 4.10 dan 4.11 dapat dilihat nilai VIF dari variabel dan nilai tolerance $>0,1$ sehingga dapat dikatakan bahwa tidak terjadi gangguan multikolinieritas yang serius.

\section{Hasil Uji Regresi Data Panel}

Tabel 4.12

\section{Hasil Uji Regresi I} Coefficients $^{\mathrm{a}}$

\begin{tabular}{|c|c|c|c|c|c|c|}
\hline \multirow[b]{2}{*}{ Model } & & \multicolumn{2}{|c|}{ Unstandardized Coefficients } & \multirow{2}{*}{$\begin{array}{c}\begin{array}{c}\text { Standardized } \\
\text { Coetficients }\end{array} \\
\text { Bela }\end{array}$} & \multirow[b]{2}{*}{1} & \multirow[b]{2}{*}{ Slg. } \\
\hline & & $B$ & Sitd Error & & & \\
\hline 1 & (Constant) & 4,563 & 3,935 & & 1,159 & .251 \\
\hline & $\begin{array}{l}\text { Kepemimpinan } \\
\text { Transakksional }\end{array}$ & 562 &, 121 &., 437 & 4,625 &, 000 \\
\hline & Kompensasi &, 424 &, 089 &, 450 & 4,764 &, 000 \\
\hline
\end{tabular}

a. Dependentt Variable: Motivasi Kerja 
Berdasarkan data dari tabel 4.12 di atas diperoleh persamaan regresi estimasi sebagai berikut:

$Z=4,563+0,562 X_{1}+0,424 X_{2}$

a. Pengaruh Gaya Kepemimpinan

Transaksional terhadap Motivasi Kerja

Berdasarkan hasil olah data variabel kepemimpinan transaksional memiliki nilai $t_{\text {hitung }}$ lebih besar dari $\mathrm{t}_{\text {tabel }}(4,625>1,999)$ dengan nilai probabilitas $(0,000)$ lebih kecil dari taraf signifikansi 0,05 , maka $\mathrm{H} 0$ diterima dan H1 diterima. Dengan demikian dapat disimpulkan bahwa kepemimpinan transaksional berpengaruh positif terhadap motivasi kerja pada karyawan PDAM Kabupaten Sleman.

b. Pengaruh Kompensasi terhadap Motivasi Kerja

Berdasarkan hasil olah data variabel kompensasi memiliki nilai $\mathrm{t}_{\text {hitung }}$ lebih besar dari $\mathrm{t}_{\text {tabel }}$ $(4,764>1,999)$ dengan probabilitas $(0,000)$ lebih kecil dari dari taraf signifikansi 0,05 , maka $\mathrm{H} 0$ diterima dan $\mathrm{H} 2$ diterima. Artinya, variabel kompensasi mempunyai pengaruh positif terhadap variabel motivasi kerja pada karyawan PDAM Kabupaten Sleman.

Tabel 4.13

Hasil Uji Regresi II

\begin{tabular}{|c|c|c|c|c|c|c|}
\hline \multirow[b]{2}{*}{ Model } & & \multicolumn{2}{|c|}{ Unstandardizad Coefficients } & \multirow{2}{*}{$\begin{array}{c}\text { Standardized } \\
\text { Coefficients } \\
\text { Betla }\end{array}$} & \multirow[b]{2}{*}{1} & \multirow[b]{2}{*}{ Sig. } \\
\hline & & B & Std Eror & & & \\
\hline \multirow[t]{4}{*}{1} & (Constant) & .782 & 2,956 & & .265 &, 792 \\
\hline & $\begin{array}{l}\text { Kepemimpinan } \\
\text { Transaksional }\end{array}$ &, 218 &, 105 & 174 & 2,080 &, 042 \\
\hline & Kompensasi &, 172 &, 078 & 186 & 2,215 &, 031 \\
\hline & Motivasi Kerja & .600 & .095 & .613 & 6,301 & 000 \\
\hline
\end{tabular}

Berdasarkan data dari tabel 4.13 di atas diperoleh persamaan regresi estimasi sebagai berikut:

$\mathrm{Y}=0,782+0,218 \mathrm{X}_{1}+0,172 \mathrm{X}_{2}+$ c. Pengaruh Gaya Kepemimpinan Transaksional terhadap Kinerja

Berdasarkan hasil olah data variabel gaya kepemiminan transaksional memiliki nilai $\mathrm{t}_{\text {hitung }}$ lebih besar dari $\mathrm{t}_{\text {tabel }}(2,080>2,000)$ dengan probabilitas $(0,042)$ lebih kecil dari dari taraf signifikansi 0,05 , maka H0 diterima dan $\mathrm{H} 3$ diterima. Artinya, variabel gaya kepemimpinan transaksional mempunyai pengaruh positif terhadap kinerja karyawan pada PDAM Kabupaten Sleman.

d. Pengaruh Kompensasi terhadap Kinerja

Berdasarkan hasil olah data variabel kompensasi memiliki nilai $t_{\text {hitung }}$ lebih besar dari $t_{\text {tabel }}$ $(2,215>2,000)$ dengan probabilitas $(0,031)$ lebih kecil dari dari taraf signifikan 0,05, maka H0 diterima dan $\mathrm{H} 4$ diterimta. Artinya, variabel kompensasi mempunyai pengaruh positif terhadap kinerja karyawan pada PDAM Kabupaten Sleman.

e. Pengaruh Motivasi Kerja terhadap Kinerja

Berdasarkan hasil olah data variabel motivasi kerja memiliki nilai $t_{\text {hitung }}$ lebih besar dari $t_{\text {tabel }}(6,301$ $>2,000)$ dengan probabilitas $(0,000)$ lebih kecil dari dari taraf signifikan 0,05, maka H0 diterima dan H5 diterima. Artinya, variabel motivasi kerja mempunyai pengaruh positif terhadap kinerja karyawan pada PDAM Kabupaten Sleman. 


\section{Sobel Test}

a. Motivasi Kerja Memediasi Antara Pengaruh Gaya Kepemimpinan Transaksional terhadap Kinerja

\section{Gambar 4.5}

Perhitungan Sobel Test

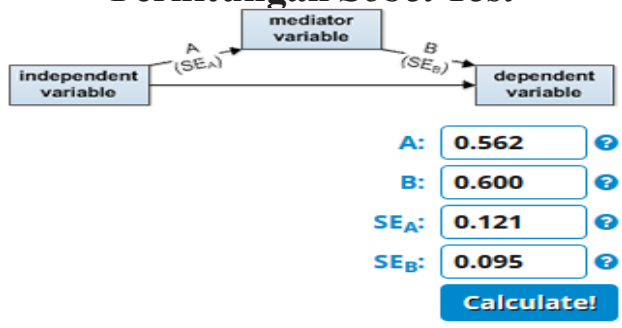

Sobel test statistic: $\mathbf{3 . 7 4 1 7 6 1 2 2}$ One-tailed probability: 0.00009137 Two-tailed probability: 0.00018274

Berdasarkan hasil perhitungan sobel test di atas didapat nilai $\mathrm{Z}$ sebesar 3,74176122. Karena nilai Z 3,74176122 lebih besar dari 1,98 $(3,74176122>1,98)$ dengan tingkat signifikansi 5\%, maka dapat diambil kesimpulan bahwa motivasi kerja mampu memediasi pengaruh gaya kepemimpinan transaksional terhadap kinerja karyawan pada PDAM Kabupaten Sleman.

b. Motivasi Kerja Memediasi Antara Pengaruh Kompensasi terhadap Kinerja

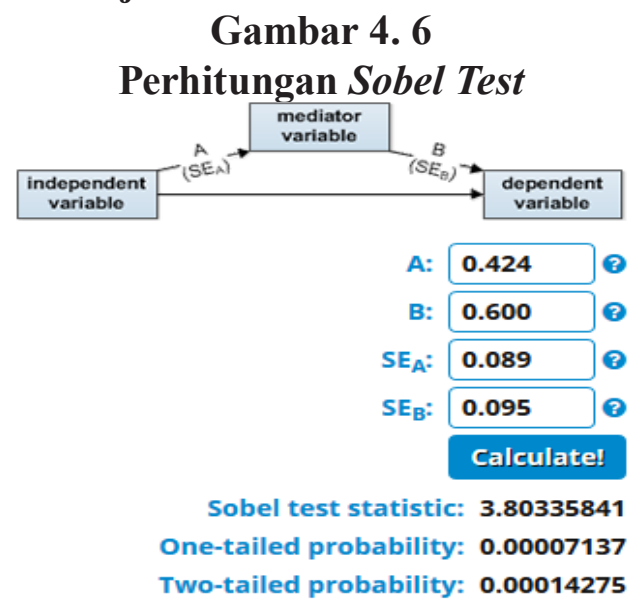

Berdasarkan hasil perhitungan sobel test di atas didapat nilai $\mathrm{Z}$ sebesar 3,80335841. Karena nilai Z 3,80335841 lebih besar dari $1,98(3,80335841>1,98)$ dengan tingkat signifikansi 5\%, maka dapat diambil kesimpulan bahwa motivasi kerja mampu memediasi pengaruh kompensasi terhadap kinerja karyawan pada PDAM Kabupaten Sleman.

\section{Hasil Uji Koefisien Determinasi}

Tabel 4.14

Hasil Uji Koefisien Determinasi Model Summary

\begin{tabular}{l}
\begin{tabular}{|l|c|r|r|r|}
\hline Model & $R$ & $R$ Square & $\begin{array}{c}\text { Adjusted R } \\
\text { Square }\end{array}$ & $\begin{array}{c}\text { Std. Error of } \\
\text { the Estimate }\end{array}$ \\
\hline 1 &, $874^{\text {a }}$ &, 763 &, 751 & 3,234 \\
\hline
\end{tabular} \\
\multicolumn{3}{|c|}{ a. Predictors: (Constant), Motivasi Kerja, Kepemimpinan } \\
Transaksional, Kompensasi \\
b. Dependent Variable: Kinerja Karyawan
\end{tabular}

Berdasarkan hasil pengujian tabel 4.14 menunjukkan bahwa nilai koefisien determinasi atau pada tabel di atas dituliskan Adjusted $R$ Square sebesar 0,751 . Hal ini diartikan bahwa besarnya kontribusi antara gaya kepemimpinan transaksional, kompensasi, motivasi kerja, dan kinerja karyawan sebesar $75,1 \%$. Sisanya $24,9 \%$ dipengaruhi oleh faktor lain yang tidak diteliti dalam penelitian ini.

\section{Standardized Beta Coeffecient} Tabel 4.15

Standardized Beta Coeffecient Standardized Beta Coeffecient

\begin{tabular}{l|c|c}
\hline \multicolumn{1}{c|}{$\begin{array}{c}\text { Variabel } \\
\text { Independen }\end{array}$} & $\begin{array}{c}\text { Variabel } \\
\text { Dependen }\end{array}$ & $\begin{array}{c}\text { Standardized Beta } \\
\text { Coeffecient }\end{array}$ \\
\hline Kep. Transaksional & Kinerja karyawan & 0,174 \\
Kompensasi & & 0,613 \\
Motivasi Kerja & & \\
\hline
\end{tabular}

Berdasarkan tabel 4.15 variabel yang paling berpengaruh dalam penelitian ini adalah motivasi kerja dengan nilai sebesar 0,613 kemudian diikuti dengan variabel kompensasi sebesar 0,186 dan diikuti lagi dengan variabel kepemimpinan transaksional sebesar 0,174. 


\section{Pembahasan}

\section{Pengaruh Gaya Kepemimpinan Transaksional terhadap Motivasi Kerja Karyawan pada PDAM Kabupaten Sleman}

Hasil penelitian menunjukan bahwa gaya kepemimpinan transaksional berpengaruh positif terhadap motivasi kerja Karyawan PDAM Kabupaten Sleman. Hasil didukung analisis regresi dengan nilai $\mathrm{t}_{\text {hitung }}$ lebih besar dari $\mathrm{t}_{\text {tabel }}$ $(4,625>1,999)$ dengan probabilitas $(0,000)$ lebih kecil dari dari taraf signifikansi 0,05. Dengan demikian, hal ini menunjukkan semakin baik gaya kepemimpinan dari pimpinan perusahaan, maka akan semakin meningkatkan motivasi kerja pada Karyawan PDAM Kabupaten Sleman.

Menurut Bass dalam Septiana (2013) gaya kepemimpinan transaksional adalah pemimpin yang mampu memberikan motivasi kepada bawahannya yang melibatkan hubungan pertukaran dengan cara menukar imbalan untuk pekerjaan yang telah dilakukannya. Kemampuan mempengaruhi yang dimiliki seorang pemimpin akan menentukan cara yang digunakan karyawan dalam mencapai hasil kerja. Dengan demikian akan mampu meningkatkan motivasi kerja dari untuk senantiasa bekerja dengan baik. Hasil penelitian ini sesuai dengan Awan (2014) dalam penelitannya menunjukkan bahwa kepemimpinan transaksional berpengaruh positif terhadap motivasi kerja.

\section{Pengaruh Kompensasi terhadap} Motivasi Kerja Karyawan pada PDAM Kabupaten Sleman

Hasil penelitian menunjukan bahwa kompensasi berpengaruh positif terhadap motivasikerjakaryawan PDAMKabupaten Sleman. Hasil didukung analisis regresi dengan nilai $\mathrm{t}_{\text {hitung }}$ lebih besar dari $\mathrm{t}_{\text {tabel }}$ $(4,764>1,999)$ dengan probabilitas $(0,000)$ lebih kecil dari dari taraf signifikan 0,05 . Dengan demikian, semakin tinggi kompensasi yang diterima karyawan, maka akan semakin meningkatkan motivasi kerja pada karyawan PDAM Kabupaten Sleman.

Kompensasi adalah segala sesuatu yang diterima oleh karyawan secara langsung maupun tidak langsung berupa imbalan maupun reward atas jasa yang telah dilakukan sesuai dengan pekerjaannya. Dengan adanya kompensasi diharapkan akan meningkatkan motivasi kerja bagi kinerja dalam melakukan pekerjaannya (Nikoyama, 2019). Pada prinsipnya karyawan berkeinginan untuk memperoleh penghasilan tinggi dari hasil pekerjaannya. Apabila kompensasi diberikan secara tepat dan benar, para karyawan akan memperoleh kepuasan dalam bekerja dan termotivasi untuk mencapai tujuan-tujuan organisasi. Sistem kompensasi yang diberikan oleh organisasi dirasa cukup adil untuk karyawan, akan mendorong karyawan untuk bekerja lebih baik dengan pekerjaan mereka dan lebih bertanggung jawab untuk setiap tugas yang diberikan. Hasil ini sesuai dengan penelitian Gerardine (n.d.) yang menunjukkan bahwa kompensasi memiliki pengaruh positif terhadap motivasi kerja.

\section{Pengaruh Gaya Kepemimpinan Transaksional terhadap Kinerja Karyawan pada PDAM Kabupaten Sleman}

Hasil penelitian menunjukkan bahwa gaya kepemimpinan transaksional berpengaruh positif terhadap kinerja Karyawan PDAM Kabupaten Sleman. Hasil didukung analisis regresi dengan nilai $\mathrm{t}_{\text {hitung }}$ lebih besar dari $\mathrm{t}_{\text {tabel }}(2,080>2,000)$ dengan probabilitas $(0,042)$ lebih kecil dari taraf signifikansi 0,05. Dengan demikian, semakin baik gaya kepemimpinan dari pimpinan perusahaan, maka mampu meningkatkan kinerja karyawan pada karyawan PDAM Kabupaten Sleman.

Menurut Insan (2017) kepimpinan transaksional merupakan kemampuan seorang pemimpin untuk mengubah 
lingkungan kerja, motivasi kerja, nilai-nilai kerja, dan sistem kerja yang dipersiapkan, sehingga karyawan mampu memaksimalkan kinerja untuk mencapai tujuan organisasi. Pemimpin organisasi dapat mempengaruhi perilaku dengan cara menciptakan sistem dan proses organisasi yang sesuai kebutuhan, baik kebutuhan individu, kebutuhan kelompok maupun kebutuhan organisasi. Pemimpin dengan gaya transaksional yang baik bisa memberikan apresiasi berupa penghargaan bagi karyawan yang berprestasi atau melebihi target yang ditentukan serta melakukan koreksi terhadap karyawan yang mempunyai terkendala pekerjaannya. Hasil penelitian ini sesuai dengan penelitiannya Amalia (2016) dan Hakim (2017) yang menunjukkan bahwa kepemimpinan transaksional berpengaruh positif terhadap kinerja karyawan.

\section{Pengaruh Motivasi Kerja terhadap Kinerja Karyawan pada PDAM Kabupaten Sleman}

Hasil penelitian menunjukkan bahwa motivasi kerja berpengaruh positif terhadap kinerja Karyawan PDAM Kabupaten Sleman. Hasil didukung analisis regresi dengan nilai $t_{\text {hitung }}$ lebih besar dari $t_{\text {tabel }}(6,301>2,000)$ dengan probabilitas $(0,000)$ lebih kecil dari taraf signifikansi 0,05. Artinya, semakin baik motivasi dari karyawan akan mampu mendorong kinerja karyawan PDAM Kabupaten Sleman.

Motivasi merupakan dorongan dan keinginan yang aktif di dalam diri manusia, yang dapat mengarahkan perilakunya untuk melaksanakan tugas dan tanggung jawab dalam lingkungan pekerjaan (Rahmawati, 2016). Kinerja karyawan dapat dinilai dari motivasi kerja mereka. Hal ini dikarenakan setiap aktifitas yang dilakukan seseorang pasti memiliki faktor yang mendorong aktifitas tersebut. Semakin tinggi bentuk motivasi yang diberikan organisasi, maka akan mendorong semangat kerja dari karyawan guna memberikan hasil kerja yang maksimal. Hasil penelitian ini sesuai dengan penelitian yang dilakukan oleh Harshanty (2011) yang menunjukkan bahwa motivasi kerja berpengaruh positif terhadap kinerja karyawan.

\section{Pengaruh Kompensasi terhadap Kinerja} Karyawan PDAM Kabupaten Sleman

Hasil penelitian menunjukkan bahwa kompensasi berpengaruh positif terhadap kinerja Karyawan Perusahaan Daerah Air Minum (PDAM) Kabupaten Sleman. Hasil didukung analisis regresi dengan nilai $\mathrm{t}_{\text {hitung }}$ lebih besar dari $\mathrm{t}_{\text {tabel }}(2,215>2,000)$ dengan probabilitas $(0,031)$ lebih kecil dari taraf signifikansi 0,05. Artinya, semakin besar kompensasi yang diterima akan mampu meningkatkan kinerja karyawan PDAM Kabupaten Sleman.

Menurut Hasibuan (2012) kompensasi adalah salah satu upaya yang dilakukan oleh perusahaan untuk meningkatkan kinerja seorang karyawan dengan memberikan timbal balik atas partisipasi yang diberikan. Pemberian kompensasi sangat penting bagi karyawan, karena besar kecilnya kompensasi merupakan ukuran terhadap kinerja karyawan. Apabila sistem kompensasi yang diberikan perusahaan cukup adil bagi karyawan, akan dapat tersebut akan mendorong karyawan untuk bekerja dengan lebih baik dalam melakukan pekerjaannya. Hasil penelitian ini sejalan dengan penelitian sebelumnya yang dilakukan oleh Nikoyama (2019) yang menunjukkan bahwa kompensasi berpengaruh positif terhadap kinerja karyawan.

6. Pengaruh Gaya Kepemimpinan Transaksional terhadap Kinerja melalui Motivasi Kerja Karyawan PDAM Kabupaten Sleman

Hasil pengujian sobel test dalam penelitian membuktikan bahwa terdapat pengaruh tidak langsung gaya 
kepemimpinan transaksional terhadap kinerja karyawan dengan motivasi kerja sebagai variabel intervening. Berdasarkan hasil perhitungan sobel test di atas diperoleh nilai $Z$ sebesar 3,74176122. Karena nilai Z 3,74176122 lebih besar dari $1,98(3,74176122>1,98)$ dengan tingkat signifikansi 5\%, maka dapat diambil kesimpulan bahwa motivasi kerja mampu memediasi pengaruh gaya kepemimpinan transaksional terhadap kinerja karyawan pada PDAM Kabupaten Sleman.

Kepemimpinan transaksional yang diterapkan dengan baik oleh pimpinan organisasi akan mampu mendorong motivasi kerja dari karyawan. Motivasi kerja yang semakin tinggi akan mendorong karyawan untuk bekerja dengan giat dan hal ini akan berdampak terhadap kinerja karyawan. Karyawan cenderung bekerja dengan lebih baik apabila mereka mempunyai motivasi yang tinggi dalam bekerja. Hasil penelitian ini sejalan dengan penelitian sebelumnya yang dilakukan oleh Septiana (2013) yang menunjukkan bahwa motivasi telah terbukti memiliki peran mediasi dalam hubungan kepemimpinan transaksional terhadap kinerja.

7. Pengaruh Kompensasi terhadap Kinerja melalui Motivasi Kerja Karyawan PDAM Kabupaten Sleman

Hasil Pengujian sobel test dalam penelitian membuktikan bahwa terdapat pengaruh tidak langsung kompensasi transaksional terhadap kinerja karyawan dengan motivasi kerja sebagai variabel intervening. Berdasarkan hasilperhitungan sobel test di atas diperoleh nilai $\mathrm{Z}$ sebesar 3,80335841 . Karena nilai Z 3,80335841 lebih besar dari $1,98(3,80335841>1,98)$ dengan tingkat signfikansi 5\%, maka dapat diambil kesimpulan bahwa motivasi kerja mampu memediasi pengaruh kompensasi terhadap kinerja karyawan pada PDAM Kabupaten Sleman.
Menurut Hasibuan dalam Dito (2010) menyatakan bahwa salah satu tujuan pemberian kompensasi adalah untuk meningkatkan motivasi kerja karyawan. Kompensasi merupakan salah satu alasan utama yang memotivasi karyawan dalam bekerja, dengan kata lain karyawan bekerja dengan tujuan untuk memperoleh kompensasi. Karyawan dengan motivasi yang tinggi akan melaksanakan pekerjaan dengan baik dan berorientasi pada tercapainya target organisasi. Hasil penelitian ini sejalan dengan penelitian sebelumnya yang dilakukan oleh Dito (2010) yang menunjukkan hasil bahwa motivasi telah terbukti memiliki peran mediasi pada pengaruh kompensasi terhadap kinerja karyawan.

\section{KESIMPULAN DAN SARAN}

\section{Kesimpulan}

Berdasarkan hasil penelitian, maka dapat disimpulkan sebagai berikut:

1. Gaya kepemimpinan transaksional berpengaruh positif terhadap motivasi kerja.

2. Kompensasi berpengaruh positif terhadap motivasi kerja.

3. Gaya kepemimpinan transaksional berpengaruh positif terhadap kinerja karyawan.

4. Kompensasi berpengaruh positif terhadap kinerja karyawan.

5. Motivasi kerja berpengaruh positif terhadap kinerja karyawan.

6. Motivasi kerja memediasi pengaruh gaya kepemimpinan transaksional terhadap kinerja karyawan.

7. Motivasi kerja memediasi pengaruh kompensasi terhadap kinerja karyawan.

\section{Saran}

1. Bagi Pimpinan Organisasi

a. Meningkatkan gaya kepemimpinan transaksional dengan cara 
memotivasi karyawannya dengan memberikan sebuah penghargaan untuk meningkatkan semangat kerja karyawan.

b. Meningkatkan kompensasi dengan cara memaksimalkan penggunaan SDM secara efektif dan efisien.

c. Meningkatkan kinerja melalui kepemimpinan transaksional dengan menerapkan motivasi melalui reward dan punishment yang efektif untuk mempertahankan karyawankaryawan yang berkualitas.

2. Bagi Penelitian Yang Akan Datang Penelitian berikutnya diharapkan dapat mengembangkan penelitian ini dengan meneliti faktor lain yang tidak terdapat pada model penelitian ini. Selain itu, memasukkan variabel lain sebagai mediasi, misalnya variabel disiplin kerja, lingkungan kerja. Hal ini diharapkan dapat memberikan hasil yang lebih baik lagi dalam memberikan informasi tentang hal-hal yang mempengaruhi kinerja.

\section{DAFTAR PUSTAKA}

Amalia, D. R., Swasto, B., \& Susilo, H. (2016). Pengaruh Gaya Kepemimpinan terhadap Motivasi Kerja dan Kinerja Karyawan. Administrasi Bisnis, 36(1), 137-146.

Awan, Taruk Todingallo Delvi.(2014). Pengaruh Kepemimpinan Transaksional terhadap Motivasi Kerja Karyawan. E-Journal Administrasi Bisnis.

Barling, J., Kelloway, F. Kelvin, \& Frone, Michael R. (1999). Handbook of Work Stress. California: Sage Publications Inc.

Deiva, D. K. (2017). Analisis Pengaruh Kepemimpinan Transaksional dan Pengembangan Karir terhadap Kinerja
Karyawan dengan Motivasi Kerja sebagai Variabel Intervening. Jurnal Administrasi Bisnis (JAB), 1-11.

Dito, A. H. (2010). Pengaruh Kompensasi terhadap Kinerja Karyawan dengan Motivasi Kerja sebagai Variabel Intervening. Journal of Chemical Information and Modeling, 1-126.

Gerardine, E., \& Belinda, G. (n.d.). Pengaruh Kompensasi terhadap Kinerja Karyawan dengan Motivasi Kerja sebagai Mediasi. Jurnal Administrasi Bisnis (JAB), 528539.

Ghozali, I. (2011). Aplikasi Analisis Multivariate dengan Program IBM SPSS 19. Penerbit Universitas Diponegoro.

Ghozali, I. (2013). Model Persamaan Struktural dengan Konsep dan Aplikasi dengan Program SPSS 21. In Jurnal Administrasi Bisnis (JAB).

Hakim, A. (2017). Pengaruh Gaya Kepemimpinan Transaksional dan Motivasi terhadap Kinerja Karyawan. E-Journal Administrasi Bisnis, 1-157.

Harshanty, A. W. (2011). Pengaruh Motivasi terhadap Kinerja Karyawan. Ilmu Ekonomi.

Hasibuan, Malayu. (2012). Manajemen Sumber Daya Manusia. Jakarta: Bumi Aksara

Insan, A. N. (2017). Pengaruh Kepemimpinan Transaksional terhadap Motivasi Intrinsik, Work Engagement dan Kinerja Karyawan. Jurnal of Business Studies, 2(1), 18.

Juliningrum, Emmy dan Achmad Sudiro. (2013). Pengaruh Kompensasi, Budaya Organisasi, terhadap Motivasi Kerja dan Kinerja Karyawan. Jurnal Aplikasi Manajemen. Volume 11. Nomor 4. 
Kasenda, R. (2013). Kompensasi dan Motivasi Pengaruhnya terhadap Kinerja Karyawan. Jurnal Riset Ekonomi, Manajemen, Bisnis Dan Akuntansi, 1(3), 853-859.

Komardi, Dadi. (2009). Pengaruh Kepemimpinan Transformasional dan Transaksional serta Motivasi Kerja terhadap Kinerja dan Kepuasan Individual Karyawan dalam Organisasi Perusahaan Industri Telekomunikasi. Jurnal Aplikasi Manajemen, Maret $7(1)$

Mahdinezhad, M., Suandi, T. Bin, Silong, A. D., \& Omar, Z. B. (2013). Transformational, Transactional Leadership Styles and Job Performance of Academic Leaders. International Education StudiesInternational Education Studies, 6(11), 29-34. https://doi.org/10.5539/ies. v6n11p29

Nikoyama, B. (2019). Pengaruh Kompensasi dan Gaya Kepemimpinan terhadap Kinerja Karyawan dengan Motivasi sebagai Variabel Intervening. Jurnal Riset Ekonomi, Manajemen, Bisnis dan Akuntansi, 1-77.

Onsardi, Moch. Asmawi, T. A. (2017). The Effect of Compensation, Empowerment, and Job Satisfaction on Employee Loyalty. International Journal of Scientific Research and Management, 05(12), 7590-7599.

Prawirosentono, Suyadi. (2008). Kebijakan Kinerja Karyawan. Yogyakarta: BPFE.

Rahmawati, F. (2016). Pengaruh Pelatihan, Motivasi, dan Kompensasi terhadap Kinerja Karyawan dengan Kepuasan Kerja sebagai Variabel Intervening.
Jurnal Ilmiah Progresif Manajemen Bisnis (JIPMB).

Rivai. (2014). Manajemen Sumber Daya Manusia untuk Perusahaan. Bandung: Remaja Rosda Karya.

Rizal, M., Idrus, M. S., \& Mintarti, R. (2014). Effect of Compensation on Motivation, Organizational Commitment and Employee Performance. International Journal of Business and Management Invention, 3(2), 64-79.

Robbins. (2011). Perilaku Organisasi. Jakarta: Salemba Empat.

Sastrohadiwiryo, B. Siswanto. (2003). Manajemen Tenaga Kerja Indonesia. Jakarta: Bumi Aksara.

Septiana, D. (2013). Peran Motivasi dalam Memediasi Pengaruh Kepemimpinan Transformasional dan Transaksional terhadap Kinerja. Journal of Chemical Information and Modeling, 53(9), 1-94.

Sobel, M. E. (1982). Asymptotic Confidence Intervals for Indirect Effect in Structural Equation Models. In S. Leinhardt (Ed.), Sociological Methodology 1982 (pp. 290-312).Washington DC: American Sociological Association

Sugiyono. (2014). Metodologi Penelitian Bisnis. Cetakan Ke Enam Belas. Bandung: Alfabeta.

Uno, Hamzah B. (2009). Teori Motivasi dan Pengukurannya. Jakarta: Bumi Aksara. 
RATNA ANDRIYA ULFAH, DIDIK SUBIYANTO, IGANATIUS SONI KURNIAWAN

Peran Mediasi Motivasi Kerja pada Pengaruh Gaya Kepemimpinan Transaksional dan Kompensasi terhadap Kinerja Karyawan 